\title{
Las cresterías mayas
}

\section{Maya Roofcombs}

\author{
Antonio Benavides C. \\ Instituto Nacional de Antropología e Historia, Centro Campeche, México
}

\begin{abstract}
ReSUmen: En la arquitectura prehispánica maya existieron diversos elementos que incrementaron el impacto visual de las construcciones. Entre ellos se encuentran las almenas o remates superiores, documentados en varios sitios de la región del Puuc, pero también presentes en los Chenes, Edzná o Chichén Itzá. Sin embargo, otro importante elemento arquitectónico de remate superior fue la crestería, cuyos orígenes datan de los primeros siglos de nuestra era, asociados a la arquitectura Petén. Tales remates fueron decorados con elementos estucados y evolucionaron hasta el periodo Posclásico; con base en sus elementos, pueden clasificarse en cuatro formatos, cuya iconografía incluyó gobernantes, deidades y motivos simbólicos.
\end{abstract}

Palabras clave: cresterías; arquitectura maya; gobernantes; dioses; símbolos.

AвSTRACT: Pre-Hispanic Maya architecture had different features that highlighted its visual impact. Among them were the battlements, like those registered in the Puuc region, but also present at the Chenes area, Edzna, or Chichen Itza. Another relevant top ending was the roofcomb, whose origins belong to the first centuries of our era and are associated with the Peten architecture. These elements were decorated with stucco images and evolved for many centuries through the Postclassic period. Considering their composition, they can be classified in four different formats, whose iconography included rulers, deities and symbolic motives.

KEYwORDS: roofcombs; Maya architecture; rulers; gods; symbols.

RECEPCIÓN: 26 de octubre de 2019.

ACEPTACIÓN: 17 de marzo de 2020.

Dol: https://doi.org/10.19130/iifl.ecm.57.2021.18652

En la arquitectura maya prehispánica existieron diversos elementos que incrementaron el impacto visual de la obra. Entre ellos se encuentran las almenas o remates superiores, documentados en varios sitios de la región del Puuc penin- 
sular, como Acanmul, Ichmac, Kabah o Xculoc, pero también presentes en los Chenes (Dzehkabtún, Santa Rosa Xtampak y Tabasqueño), en Edzná o en Chichén Itzá (Gendrop, 1983; 1997; Benavides, 2016). Otro tipo importante de remate superior fue la crestería, en ocasiones lograda mediante un voluminoso macizo casi completo de mampostería, como se aprecia en los templos más elevados de Tikal, en Guatemala. Esas primeras cresterías se erigieron dejando espacios interiores muy reducidos, pero conforme la arquitectura maya evolucionó, las construcciones de siglos posteriores ampliaron las dimensiones de las habitaciones y aligeraron la forma de las cresterías. Si bien hoy casi no se aprecian los detalles, la intención primordial de las masivas cresterías de Tikal fue ensalzar la figura de los dirigentes vinculados con las deidades.

Un buen inventario de cresterías fue iniciado por Paul Gendrop (1975; 1983 : $187,189 ; 1985)$, quien documentó a detalle diversos ejemplos existentes en varias regiones del mundo maya. Las clasificó en tres tipos: Petén (superestructura voluminosa, con o sin huecos integrales, cargada hacia la parte posterior del techo), Palenque (superestructura ligera —-doble o múltiple — cargada hacia la parte central del techo), y peninsular (superestructura simple, usualmente delgada y rítmicamente calada, cargada hacia el frente o en el centro del techo).

Los orígenes de las cresterías están entonces asociados a la arquitectura Petén (primeros siglos de nuestra era), donde predominaron amplios macizos de mampostería con cámaras de reducido tamaño. Tikal cuenta con varios ejemplos en sus mayores templos, como los denominados I y II que conforman la Gran Plaza, así como el imponente Templo IV (Coe, 1965; 1967; Harrison, 1999) (Figuras 1 y 2). Casos similares de cresterías existían en otros sitios como Nakum, Río Azul y El Mirador. Posiblemente también las hubo en Calakmul, si bien hasta ahora las excavaciones no lo han confirmado.

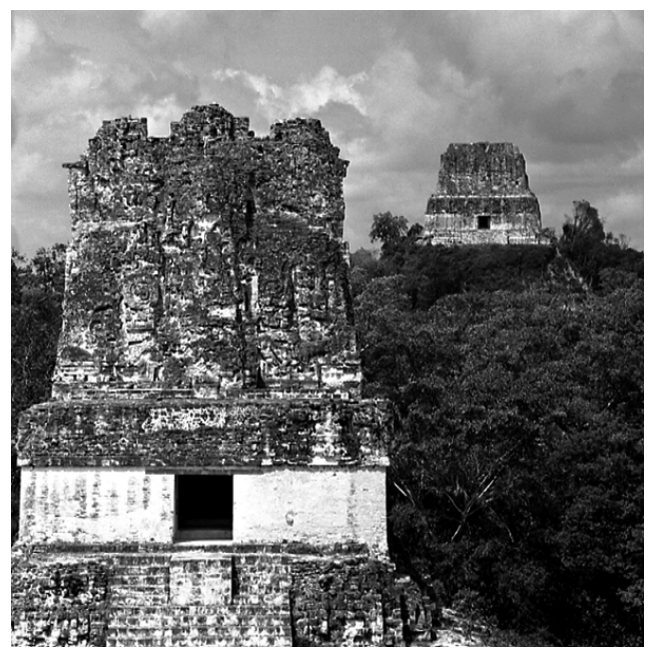

Figura 1. Tikal, Templos II y IV, al fondo (Según Beatriz de la Fuente, 1970: lám. 9). 


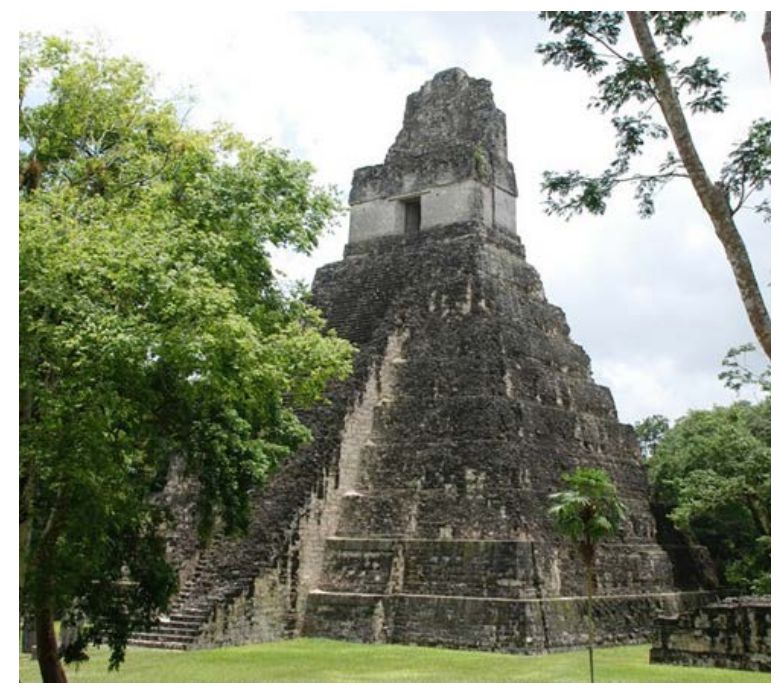

Figura 2. Tikal, Templo I (Fotografía de Antonio Benavides C.).

También debemos recordar los remates superiores registrados en otras cuatro construcciones del Petén que no se levantaron sobre los templos erigidos encima de los basamentos piramidales, sino sobre edificios de varias habitaciones: Pared de los Reyes, La Muralla y Olvidado (dos ejemplos). Un caso similar, pero muy lejos del Petén, se encuentra en la Estructura IX del Grupo Nohoch Mul de Cobá, Quintana Roo (Benavides, 1981: 64, figs. 23 y 24). En los primeros casos se trata de muros de mampostería con algunas caladuras verticales que los atraviesan y vestigios de figuras humanas logradas con estuco modelado. Las dimensiones anotadas para la crestería de Pared de los Reyes fueron $20.60 \mathrm{~m}$ de largo por $2.98 \mathrm{~m}$ de alto y un grosor de $1.20 \mathrm{~m}$ en la base por $75 \mathrm{~cm}$ en la parte superior (Ruppert y Denison, 1943: 69-70, fig. 86, láms. 27 y 28). En contraste, el remate cimero de La Muralla fue registrado con $17.60 \mathrm{~m}$ de largo por $5 \mathrm{~m}$ de alto y una anchura de $1.63 \mathrm{~m}$ (Ruppert y Denison, 1943: 71-73, fig. 89, láms. 29 y 30). La crestería del Edificio 1 de Olvidado cubre unos $26 \mathrm{~m}^{2}$, mientras que la del Edificio 2 ocupa unos $60 \mathrm{~m}^{2}$ (Sprajc, 2008: 98-101).

La crestería de Pared de los Reyes contó con tres series de aberturas, cada una con ocho caladuras, alineadas verticalmente. La primera serie de caladuras fue hallada al nivel de la base, cada una con $16 \mathrm{~cm}$ de ancho por $25 \mathrm{~cm}$ de altura. La segunda serie de aberturas se halló a los $96 \mathrm{~cm}$ de altura con respecto al techo. Ahora los vanos midieron $18 \mathrm{~cm}$ de ancho por $38 \mathrm{~cm}$ de alto. La tercera serie de caladuras distaba $10 \mathrm{~cm}$ de la segunda y sus vanos tuvieron también $18 \mathrm{~cm}$ de ancho, pero $52 \mathrm{~cm}$ de altura. La distribución de las aberturas conformaba nueve paneles, cada uno con un promedio de 2.25 de ancho sobre los que existían imágenes de personajes, algunos de pie y otros sentados, logrados en 
estuco modelado. Esos elementos son los que dieron nombre a la estructura en la década de 1930.

Por su parte, la crestería de La Muralla también tuvo nueve sectores verticales formados por las series de caladuras. Sobre esos paneles y en ambos lados también se registraron figuras humanas elaboradas con estuco. Algunos personajes estaban sentados, otros de pie, algunos sedentes con las piernas cruzadas e incluso uno de rodillas.

Después, en la cuenca del río Usumacinta se erigieron gráciles muros calados, como en la Estructura 33 de Yaxchilán (García Moll, 2003: 198-216) (Figuras 3 y 4) o en la Estructura O-13 de Piedras Negras (Scherer, 2015: 182). A unos $100 \mathrm{~km}$ al noroeste, algo similar se hizo en los Templos del Sol y de la Cruz de Palenque (Marquina, 1964: 640-643; Garza, Bernal y Cuevas, 2012: láms. 14 y 16). En estos últimos casos la solución más común fue levantar dos muros a los que se abrieron varias oquedades o caladuras como parte de un diseño simbólico-decorativo. Sobre dichos muros se aplicaron motivos estucados y policromados con imágenes de gobernantes y su parafernalia. Los varios ejemplos de cresterías caladas palencanas han llevado a considerarlas como las más "ligeras, aéreas u osadas" del mundo maya.

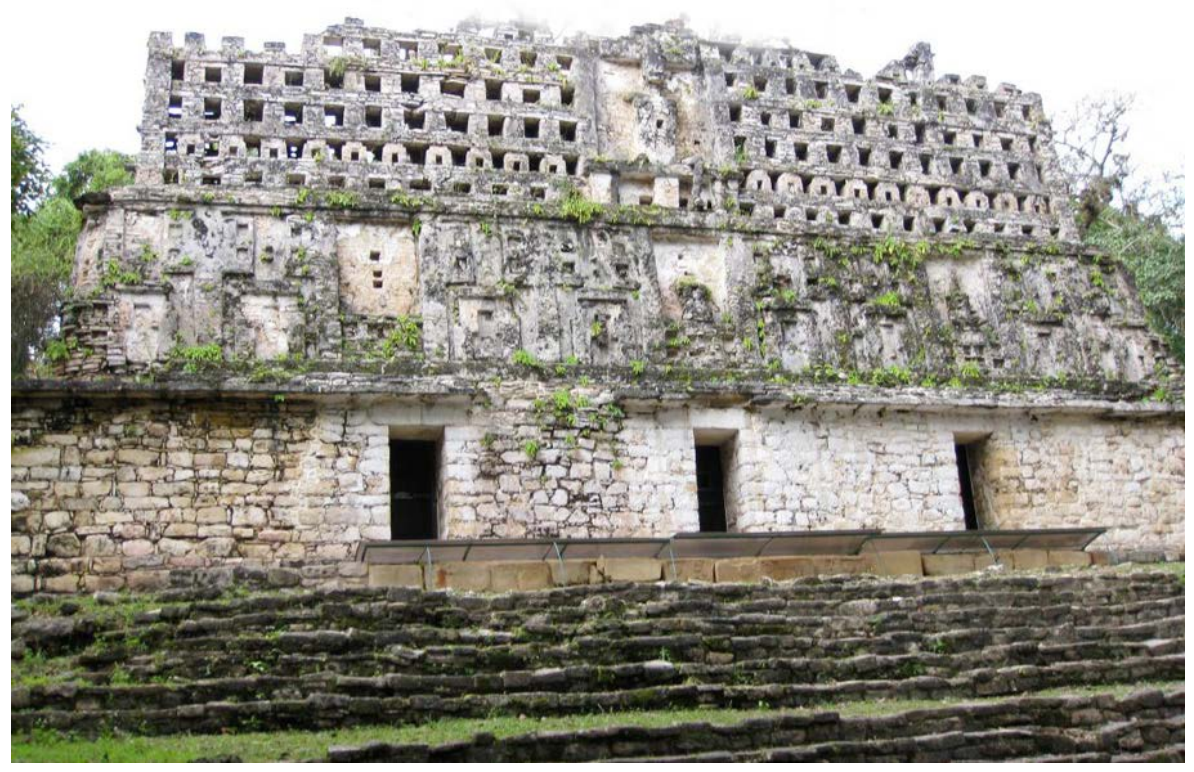

Figura 3. Edificio 33 de Yaxchilán, Chiapas (Fotografía de Akira Kaneko).

De acuerdo con Merle Greene (1979), quien registró y analizó durante muchos años los elementos arquitectónicos y decorativos de Palenque, esas cresterías 


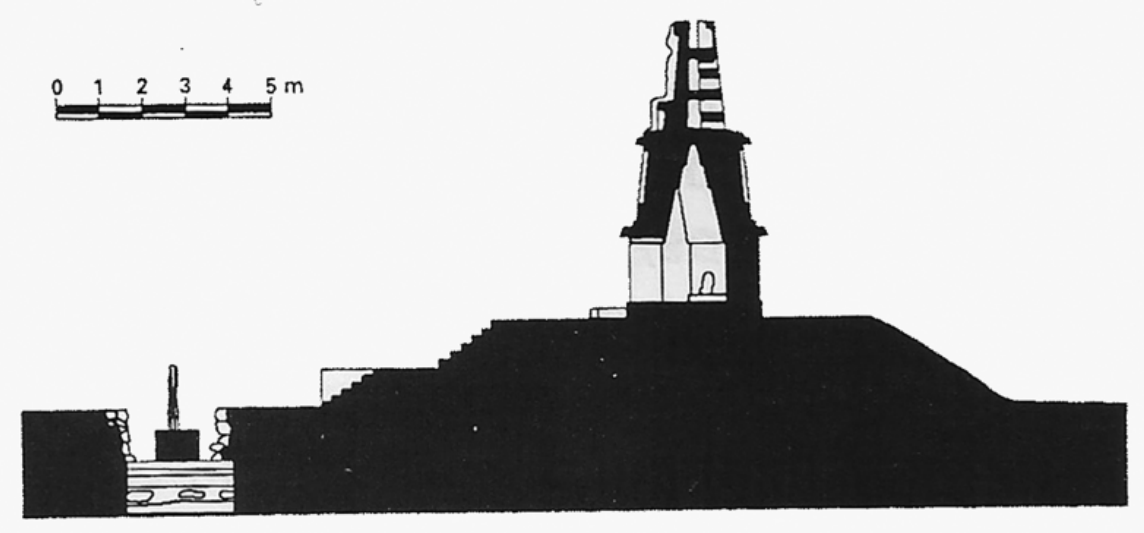

Figura 4. Corte del Edificio 33 de Yaxchilán, Chiapas (Tomado de García Moll, 2003).

tuvieron motivos de estuco modelado y policromado. Gracias a su tesón y fino registro, por ejemplo, Greene analizó las imágenes que Alfred Maudslay logró en 1890 con grandes negativos de cristal y, trabajando en el Templo del Sol, durante varias temporadas, documentó minuciosamente los vestigios existentes. Así pudo elaborar una detallada reconstrucción de la crestería, en donde se aprecia un gran mascarón del Monstruo de la Tierra, de cuya frente hendida surge la figura sedente de un gobernante. Éste sostiene una barra de mando con cabezas serpentinas en ambos extremos. Cuatro figuras de dioses flanquean a los elementos anteriores y toda la escena es enmarcada por los bordes de la crestería, en donde aparecen cartuchos rectangulares con símbolos celestes (la vía láctea, Venus, el Sol, la Luna, etc.). Predominan los colores azul y rojo, pero también hay elementos anaranjados y ocres (Figuras 5 y 6 ).

Otro sitio que tuvo cresterías caladas y se encuentra a unos $130 \mathrm{~km}$ al sur de Palenque es Toniná, si bien los vestigios conservados sólo dejan ver algunas evidencias y muretes que forman la base del remate.

En la región de Río Bec también encontramos cresterías. Las mejor conservadas se hallan en Okolhuitz, Chicanná y Río Bec B. En el caso de Okolhuitz, ubicado a unos $10 \mathrm{~km}$ al sureste de Xpuhil, existe una crestería con calados en forma del signo $i k$ (una letra $\mathrm{T}$, pero aquí invertida), a ambos lados del motivo central. En este caso los constructores diseñaron un gran mascarón antropomorfo del Monstruo de la Tierra como base de un individuo representado de pie y provisto de la indumentaria y los elementos correspondientes a un funcionario de alto rango (Ruppert y Denison, 1943; Benavides, 2004) (Figuras 7 y 8). 


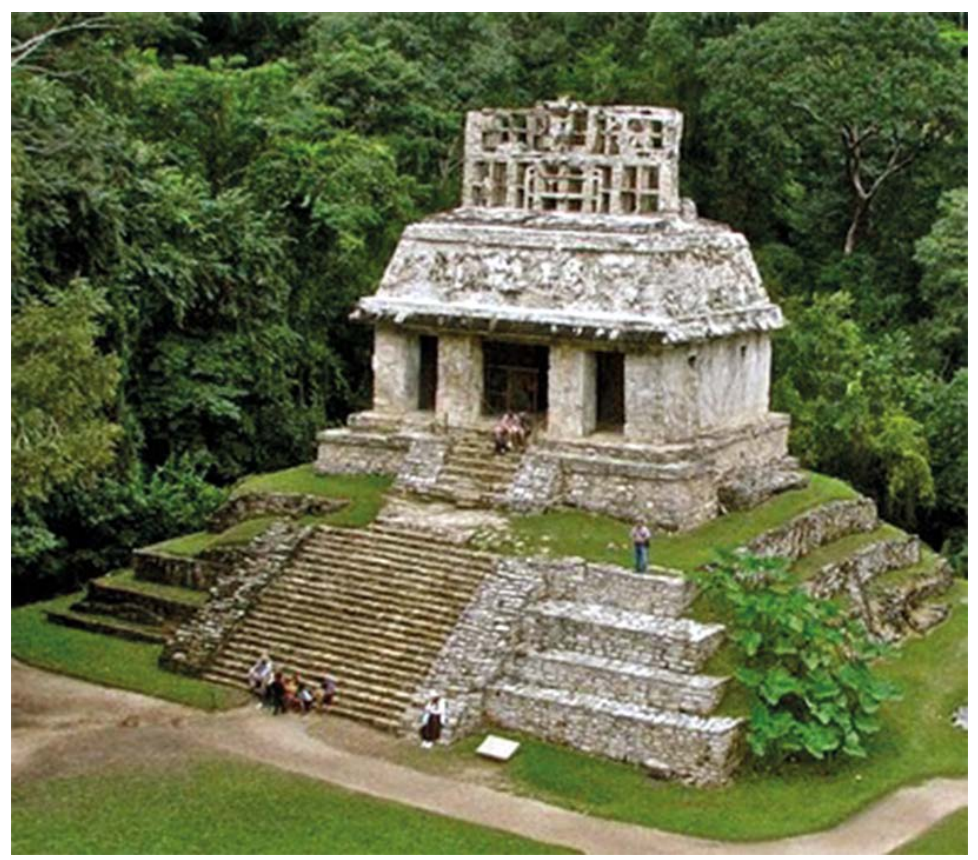

Figura 5. Palenque, crestería del Templo del Sol (Fotografía de Antonio Benavides C.).

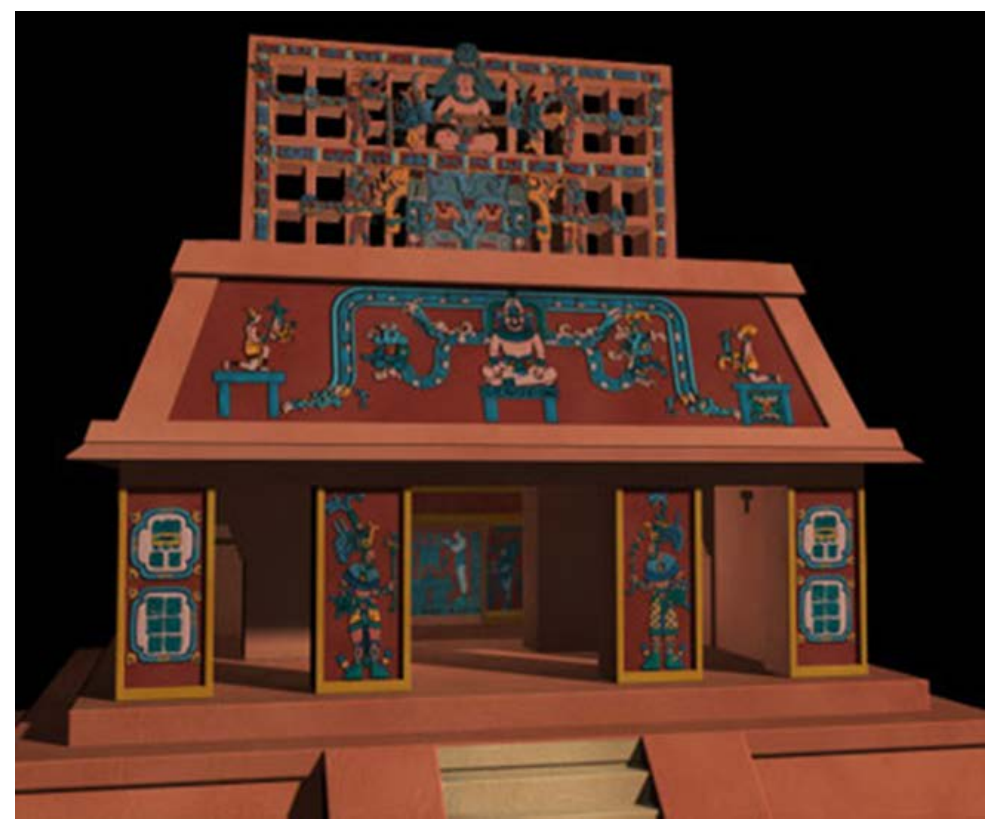

Figura 6. Reconstrucción del Templo del Sol, por Merle Greene (1979). 


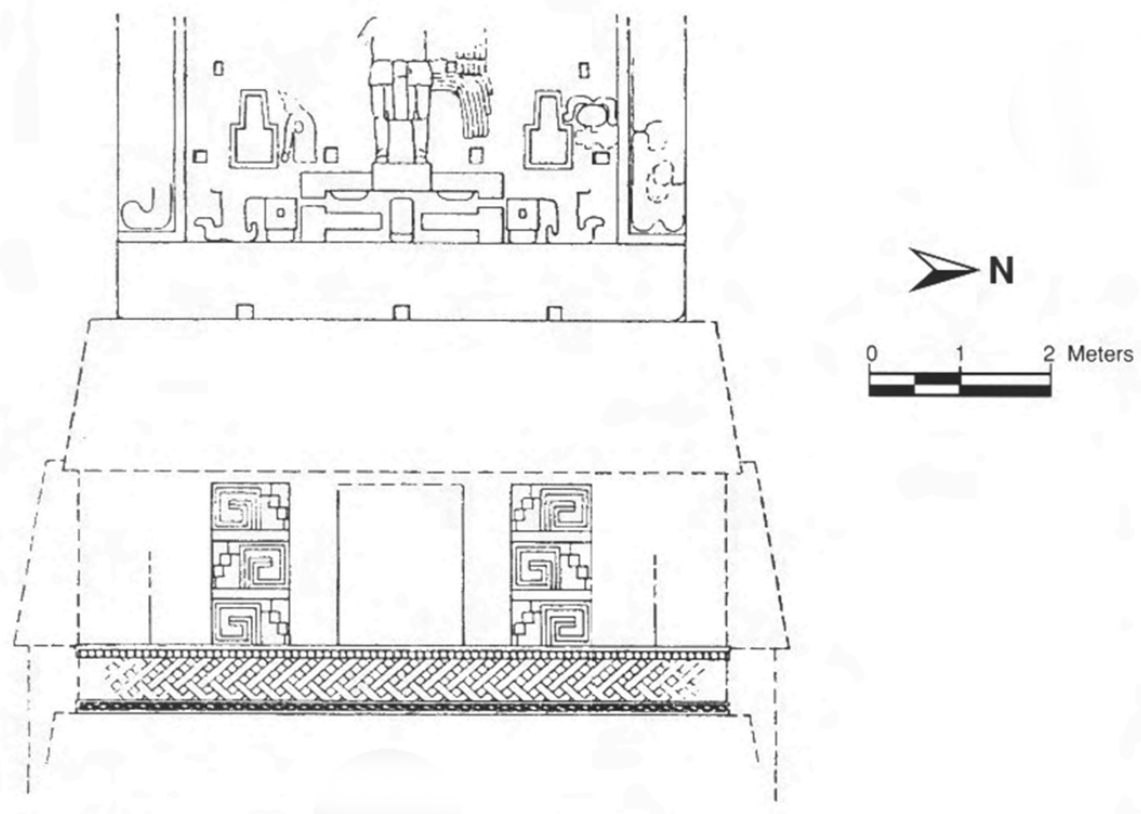

Figura 7. Crestería de Okolhuitz, Campeche (Según Ruppert y Denison, 1943).

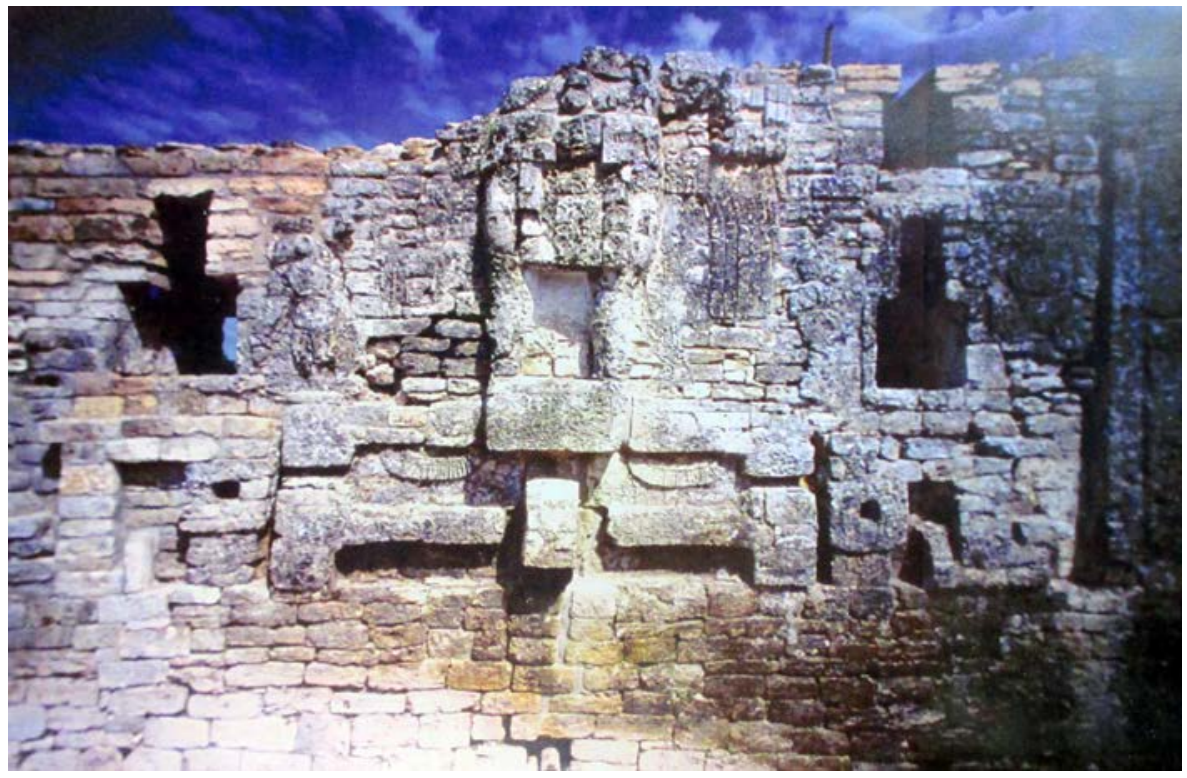

Figura 8. Detalle de la crestería de Okolhuitz, Campeche (Fotografía de Nicholas Hellmuth). 
Esta construcción de Okolhuitz contó con tres aposentos abovedados y muestra la transición de las edificaciones mayas peteneras ocurrida entre los siglos VII y vill de nuestra era. El sistema constructivo de sus altas y angostas habitaciones revela los cánones de la arquitectura Petén (por ejemplo, los sillares toscamente cortados, con un grueso repello de estuco); pero la manufactura de la crestería, lograda con sillares pequeños muy bien cortados y ensamblados, además de la rica variedad de detalles en estuco modelado, revela la clara presencia de la arquitectura Río Bec.

En Río Bec B la construcción principal luce muros calados sobre el aposento del sector central y, evidentemente, las torres que flanquean la construcción alcanzaron mayor altura (Michelet, Latsanopoulos y Patrois, 2004; Michelet, Arnauld y Nondédéo, 2007). Si bien sólo se conservan dos terceras partes de la crestería ubicada al centro del inmueble, es posible que haya ocupado unos $38 \mathrm{~m}^{2}$. A principios de 2018, Ricardo Torres Marzo (comunicación personal) registró otro edificio con crestería en Pasión del Cristo, a pocos kilómetros del poblado 20 de Noviembre.

Más al norte, en la Estructura VI de Chicanná se observa un muro con delgadas caladuras verticales separadas casi cada metro. Encima de ello el muro continúa, pero en él las caladuras se hallan más cercanas entre sí y todavía arriba hay una segunda hilada de calados, pero de menor longitud. La Estructura XX de Chicanná es de mayor volumen (tiene dos niveles) y aparentemente su crestería fue como la del edificio previo, pero sólo se ha conservado la parte inferior del muro (Figuras 9 y 10).

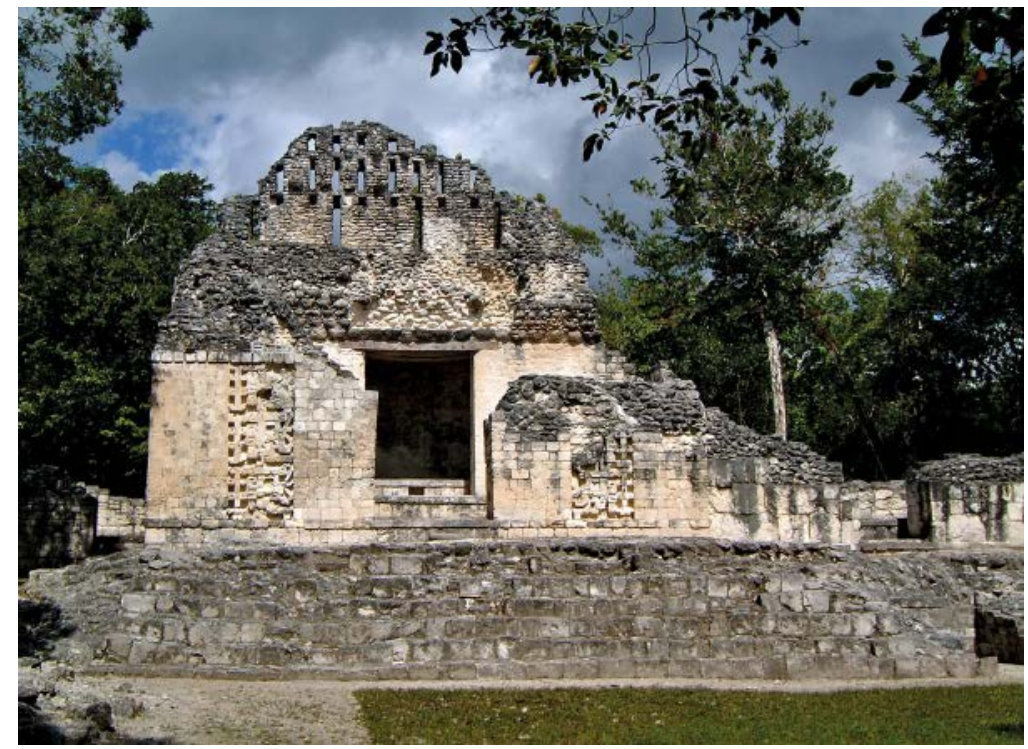

Figura 9. Estructura VI de Chicanná (Fotografía de Antonio Benavides C.). 


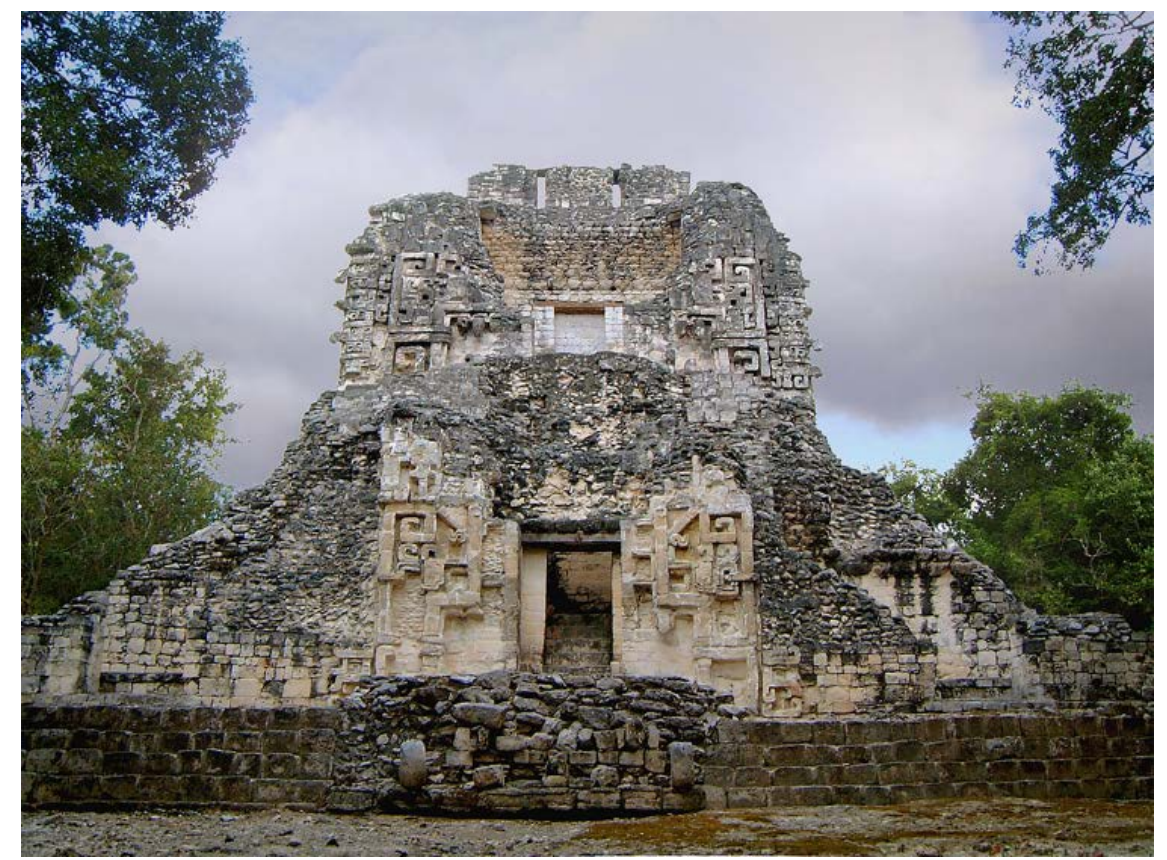

Figura 10. Estructura XX de Chicanná (Fotografía de Antonio Benavides C.).

Veamos ahora algunos casos de la región de los Chenes. En el noreste de Campeche, Robina (1956) reportó los vestigios de una crestería sobre el techo de la Estructura II de Hochob. Basada en evidencias arqueológicas, la reconstrucción hoy visible en la Sala Maya del Museo Nacional de Antropología de la Ciudad de México indica que posiblemente contó con figuras antropomorfas de pie dispuestas en dos niveles (Figura 11). En Hochob hoy sólo pueden verse ocho pilastrones de menos de medio metro de altura. Las Estructuras V y VI de Hochob también tuvieron cresterías, si bien esas evidencias casi no se han conservado y solamente se aprecia un patrón de caladuras verticales.

A unos $10 \mathrm{~km}$ al norte de Hochob se encuentra Tabasqueño, donde existen los vestigios de otra crestería calada sobre el Palacio-Templo, inmueble originalmente reportado por Teobert Maler a fines del siglo xix. El corte arquitectónico elaborado por Maler (1997: 103) indica que el remate contó con tres cuerpos que se adelgazaban conforme ganaban altura, aún mostraba un enlucido pintado de rojo y posiblemente alcanzó unos $4 \mathrm{~m}$ de altura.

Dzehkabtún, también en la región Chenes, conserva a su vez una construcción coronada por un muro calado que también reportó inicialmente Maler (1997: 9799, láms. 37 y 38). Es una construcción de seis habitaciones sobre las que se erigió una crestería de $14 \mathrm{~m}$ de largo por $1.20 \mathrm{~m}$ de ancho en su base y $7 \mathrm{~m}$ de alto. Tuvo cinco niveles, cada uno con caladuras verticales, algunas cuadrangulares, y 


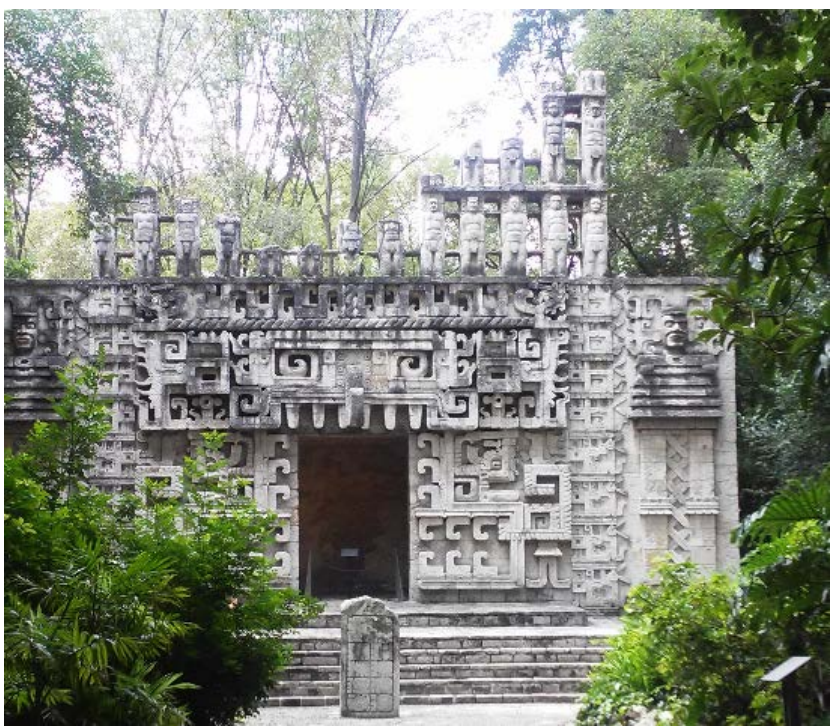

Figura 11. Reconstrucción parcial de la crestería de la Estructura II de Hochob, mNA (Fotografía de Antonio Benavides C.).

espigas para soportar elementos de estuco modelado. Al centro del costado sur se conservan los vestigios de un gran mascarón. Como detalle interesante cabe comentar que en la exploración del lado sur se registraron varias almenas que debieron provenir del techo de las habitaciones (Paap y Benavides, 2015) (Figura 12).
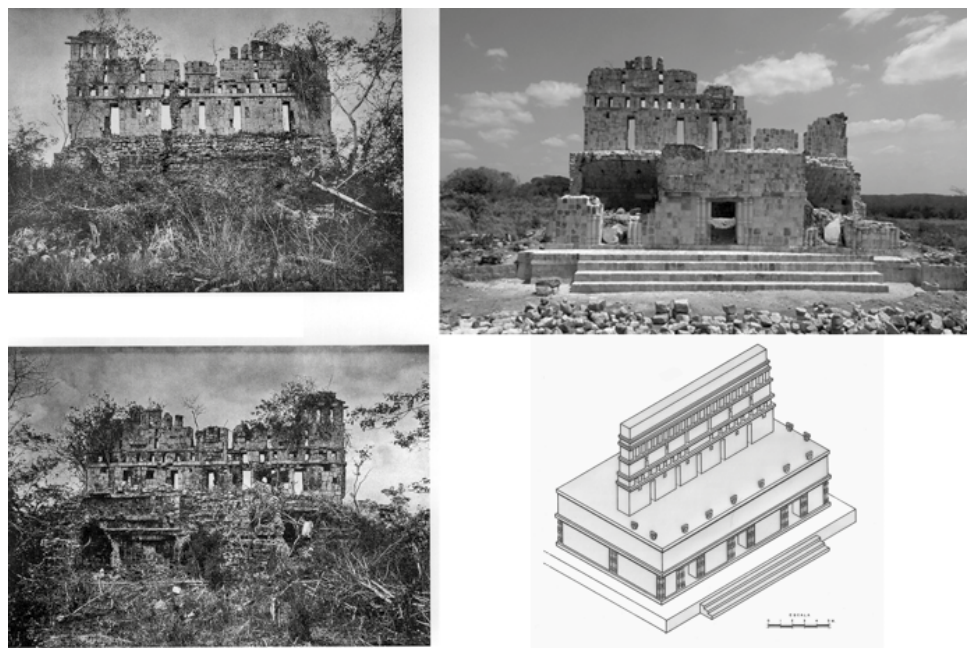

Figura 12. A la izquierda, arriba y abajo, los registros realizados por Maler (Según Maler, 1997); arriba a la derecha, el inmueble restaurado, y abajo a la derecha, su reconstrucción hipotética (Foto y dibujo de Antonio Benavides C.). 
A unos $40 \mathrm{~km}$ al suroeste del sitio anterior se encuentra Edzná, cuyo Edificio de los Cinco Pisos conserva prácticamente un $60 \%$ de su crestería, donde nuevamente apreciamos series de calados rectangulares en sentido vertical. La proporción entre la altura del templo y la de la crestería es casi la misma: $6.30 \mathrm{~m}$ de los aposentos versus $5.70 \mathrm{~m}$ de la crestería (Benavides, 1997: 47; 2012; 2014: 41, 96). En este remate también encontramos espigas de piedra en ambos paños, lo cual indica que seguramente hubo imágenes de estuco modelado y pintado (Figura 13).

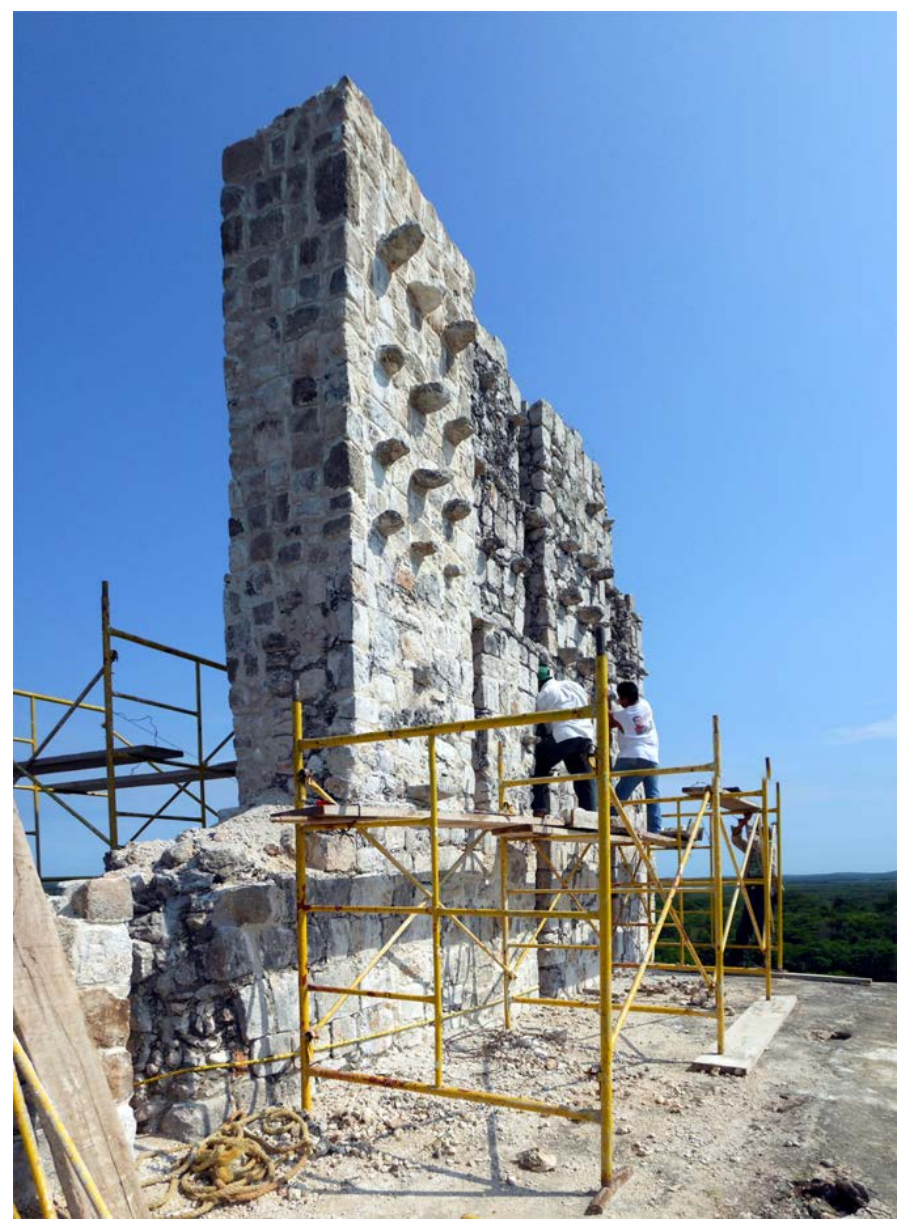

Figura 13. Edzná. Lado este de la crestería del Edificio de los Cinco Pisos (Fotografía de Antonio Benavides C.).

En otro sector septentrional de Campeche, a unos $50 \mathrm{~km}$ al norte de Edzná, encontramos un interesante ejemplo de crestería propia de la arquitectura Puuc temprana: el caso del Edificio 1 de Kankí, en el municipio de Tenabo. El centro de 
la representación es ocupado por un mascarón de prominente nariz. Sus ojos son dos vanos y la boca fue lograda en estuco, material que también formó diversos relieves en el costado oriental de la crestería. A cada lado del rostro fantástico hay otras dos caladuras, ahora dispuestas en sentido vertical y que brindan mayor luz a la composición (Figuras 14 y 15).

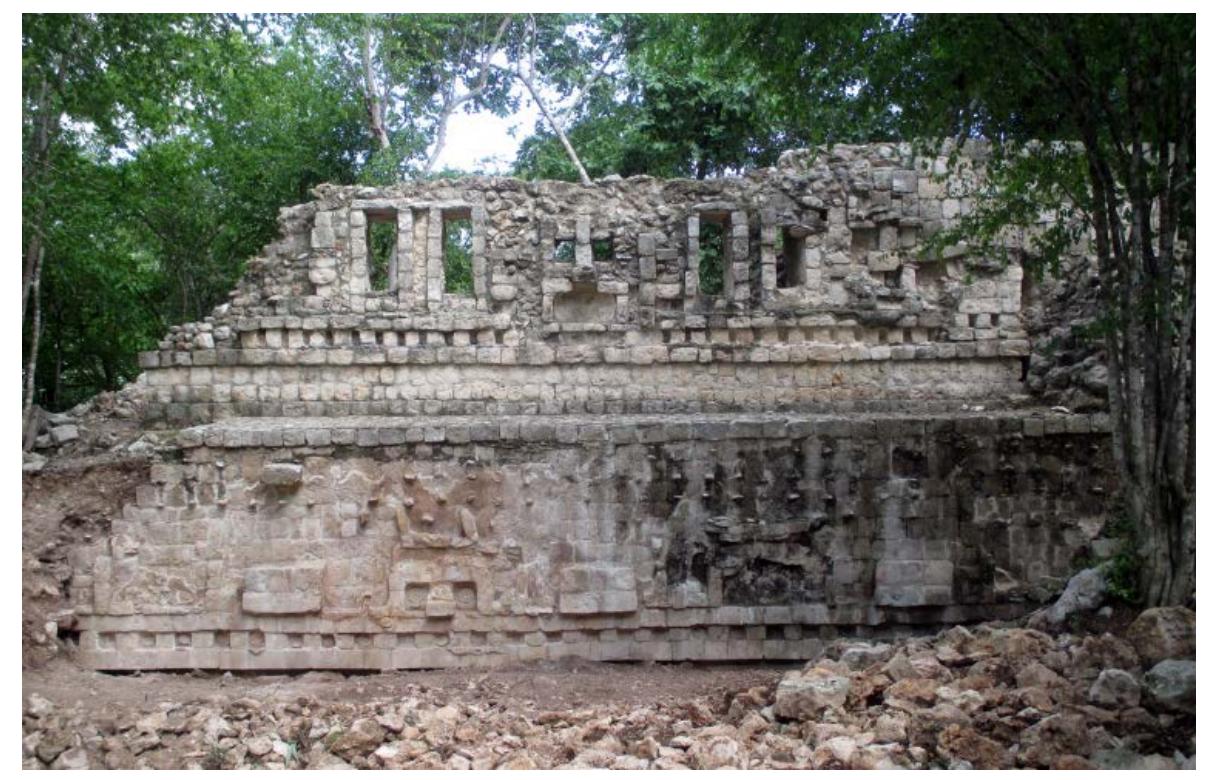

Figura 14. Crestería del Edificio 1 de Kankí (Fotografía de Antonio Benavides C.).

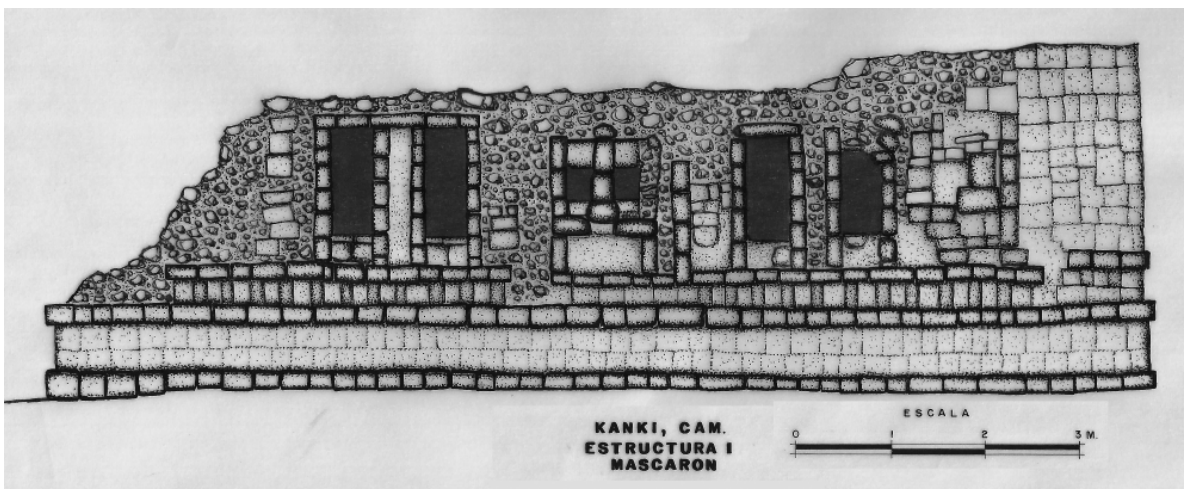

Figura 15. Crestería del Edificio 1 de Kankí (Dibujo de Antonio Benavides C.).

Otros sitios del norte campechano fueron Xcacabcutz (cerca de Edzná) (Andrews, 1995; 1997), Chelemí y Xuelén. Los tres tuvieron edificios coronados por 
cresterías. Durante los trabajos de conservación de Xuelén se recuperaron múltiples fragmentos de estuco modelado, entre ellos la representación de un rostro humano (Benavides, 1998a; 1998b).

Yendo más al norte del mundo maya, en la región del Puuc existen varios ejemplos bien documentados de cresterías en los que la regla parece haber sido también un estricto apego a la simetría. Estamos hablando de cresterías como las que se conocen en Labná, Sabacché, Sayil o Sacnicté (Pollock, 1980; Maler, 1997). En ellas encontramos un patrón de rectángulos sólidos combinados con espacios vacíos. Para soportar ese peso extra las cresterías fueron construidas sobre los muros de carga ubicados inmediatamente debajo, ya fuese en el muro que dividía dos aposentos o bien sobre el muro de la fachada. Las caladuras también ayudaron a restar peso y facilitaron el paso del viento.

Sobre los macizos se desplegaban los elementos de estuco modelado que interesaba fueran vistos por la población. En la Estructura 4 de Labná, por ejemplo, el registro de vestigios estucados indica que hubo varias escenas, entre ellas, la de un juego de pelota, además de figuras humanas en las esquinas (Pollock, 1980: 34-38). Las ilustraciones iniciales de Stephens (1963, 2: 50-53) y las fotografías y descripción de Edward H. Thompson (1889: 97-104) muestran que se conservaban más motivos de estuco. Algunos elementos de interés por ellos registrados y que ya no son visibles son una hilera de cráneos encima del borde superior de la crestería (¿tzompantli?), dos figuras humanas con una pelota entre ellas y una gran figura sentada sobre el acceso central cuyo tocado conservaba pintura roja y azul. Aquí cabe comentar que la imaginería de la crestería de Labná aprovechó la superficie del paramento superior de la fachada, dado que el remate se construyó sobre el muro delantero del edificio.

De menores dimensiones, pero también como ejemplo de una crestería maya, lo encontramos en Chunyaxnic, próximo al poblado del mismo nombre, en el sector norte de Campeche y al oriente de Nohalal. Corona la Estructura 1 , ubicada casi en la cúspide de una colina de poco menos de $30 \mathrm{~m}$ de altura. La parte superior de la fachada es una crestería calada que se conservó a una altura máxima de $2.10 \mathrm{~m}$. El muro tiene un grosor de $50 \mathrm{~cm}$ y cuando menos tuvo dos niveles. El inferior tiene tres caladuras verticales rematadas por una moldura sencilla y en el segundo nivel tuvo cuatro vanos rectangulares (Figuras 16 y 17). El sistema constructivo general, la pequeña moldura quebrada que se aprecia sobre el vano de entrada y el uso de lajillas para revestir la crestería confirman la pertenencia a la fase Puuc Temprano. Otro elemento indicativo de la temporalidad es el uso de varios sillares para conformar las jambas del acceso. Los intradoses de la bóveda están formados por diferente número de hiladas de recubrimiento y describen curvas irregulares (Benavides y Novelo, 2007). La primera persona en reportar Chunyaxnic fue también Teobert Maler (1997: 59, láms. 30 y 31). 


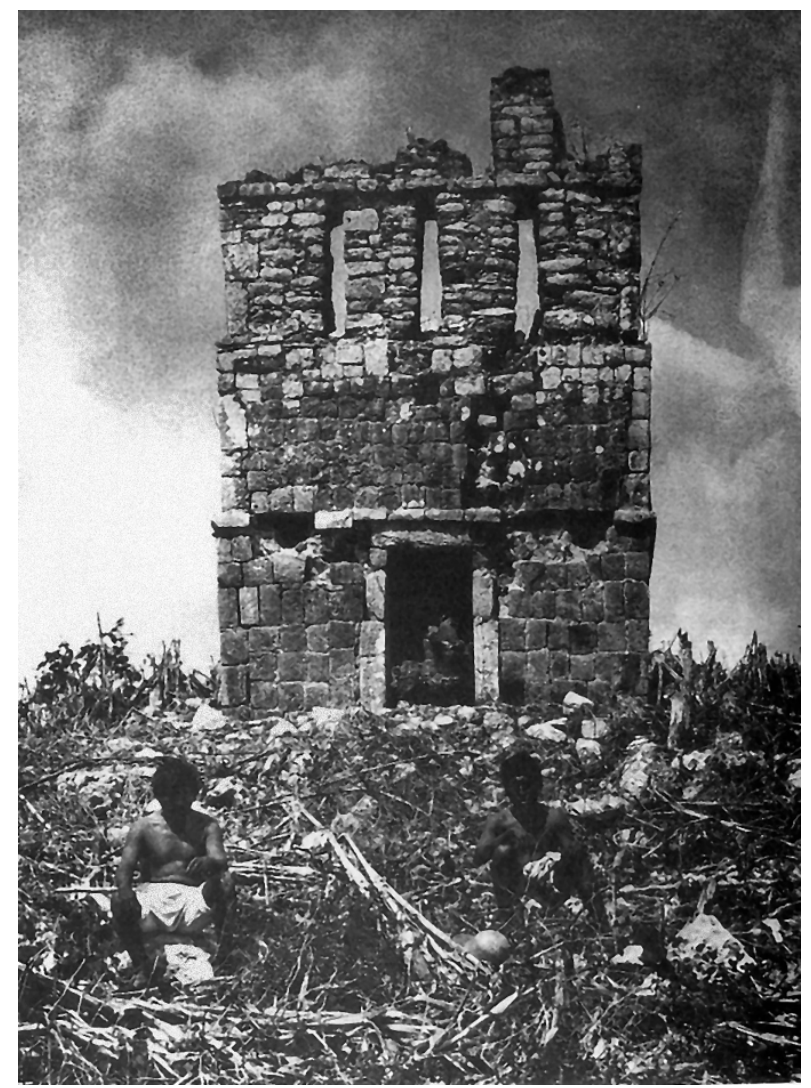

Figura 16. Edificio principal de Chunyaxnic, Campeche (Según Maler, 1997).

Existen otros dos ejemplos de cresterías pequeñas en el norte de Campeche: Chanchén y Nocuchich. En ambos casos se trata de torres, la primera de planta rectangular y la segunda cuadrangular, cuyas bases no sobrepasan los $4 \mathrm{~m}^{2}$ de superficie. Recordando los elevados remates de los templos mayas, ambas torres lucen en la parte superior sendos muretes con calados verticales. Nocuchich tiene una altura promedio de $9.50 \mathrm{~m}$, mientras que Chanchén pudo haber alcanzado los $8.50 \mathrm{~m}$.

Otro buen ejemplo de las cresterías mayas del Puuc puede verse en la Casa de las Palomas o el Palomar, de Uxmal, en donde al techo de 12 habitaciones se agregó un largo muro calado de unos 70 metros de largo por $80 \mathrm{~cm}$ de ancho y una altura promedio de 7 metros. Además, la parte superior de dicha crestería juega con formatos triangulares que también van calados (Marquina, 1964; Pollock, 1980: 248; Graham, 1992). En ese mismo sitio hubo otro interesante ejemplo de crestería rematada en triángulos en el templo inferior de la Casa de la Vieja (Pollock, 1980: 254-256). 


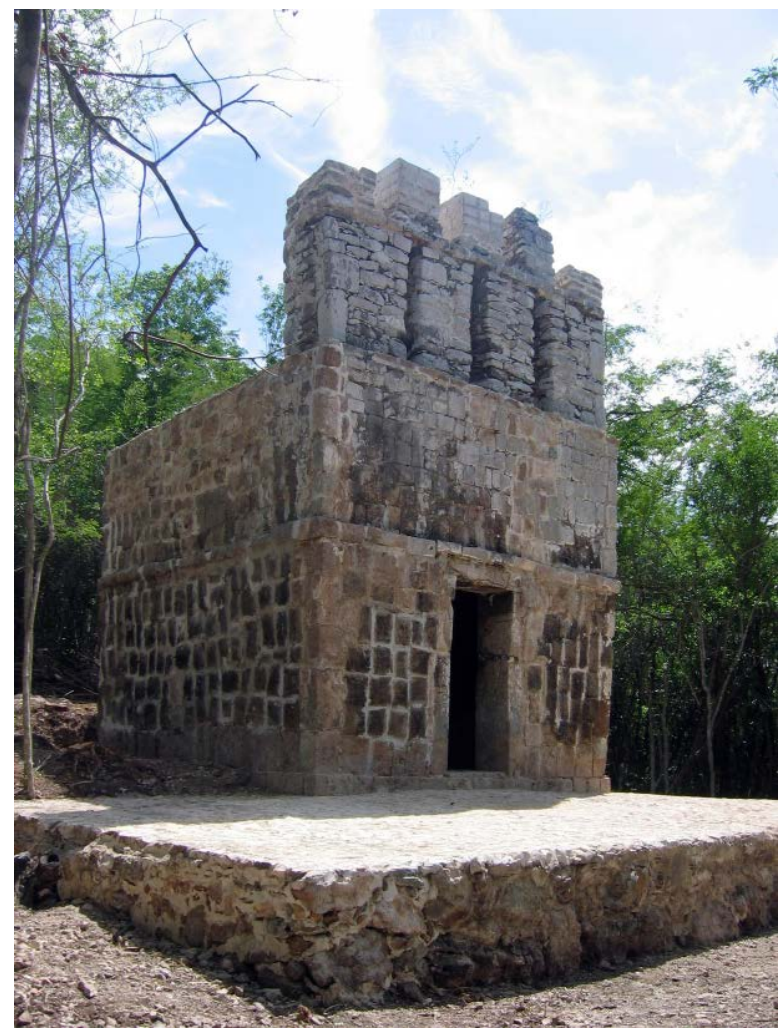

Figura 17. Edificio principal de Chunyaxnic tras su consolidación (Fotografía de Antonio Benavides C.).

A la par de las cresterías verticales, cabe recordar que en la región del Puuc también se construyeron remates horizontales de carácter simbólico-decorativo, por ejemplo en Kupaloma, cerca de Oxkintok (Andrews, 1986: 21), donde vemos rectángulos y cruces; o bien, en Mul Chic, donde hubo dos niveles de calados verticales (Piña Chán, 1964: 70). Otro interesante ejemplo construido pocos siglos después es el muro de unos $40 \mathrm{~m}$ de largo que remata el Codz Poop de Kabah (Pollock, 1980: 187). Ahí vemos una larga serie de caladuras verticales sobre la que se elaboró una serie continua de grecas escalonadas. Esa crestería, en promedio, debió tener unos $4.50 \mathrm{~m}$ de altura. Las fechas registradas en las jambas del edificio (859 y 873 d.C.) permiten fecharlo en la segunda mitad del siglo ix (Stuart, 2014).

Para el periodo Clásico Terminal (ca. 1000 d.C.), encontramos otros ejemplos de remates superiores en la llamada Casa Roja o Chichanchob de Chichén Itzá. En ese edificio una crestería recorre el eje central de la azotea, pero además cuenta con otro muro calado encima de la fachada (Figura 18). A su vez, el inmueble 
conocido como La Iglesia también luce una crestería erigida sobre el muro de la portada principal (Figura 19).

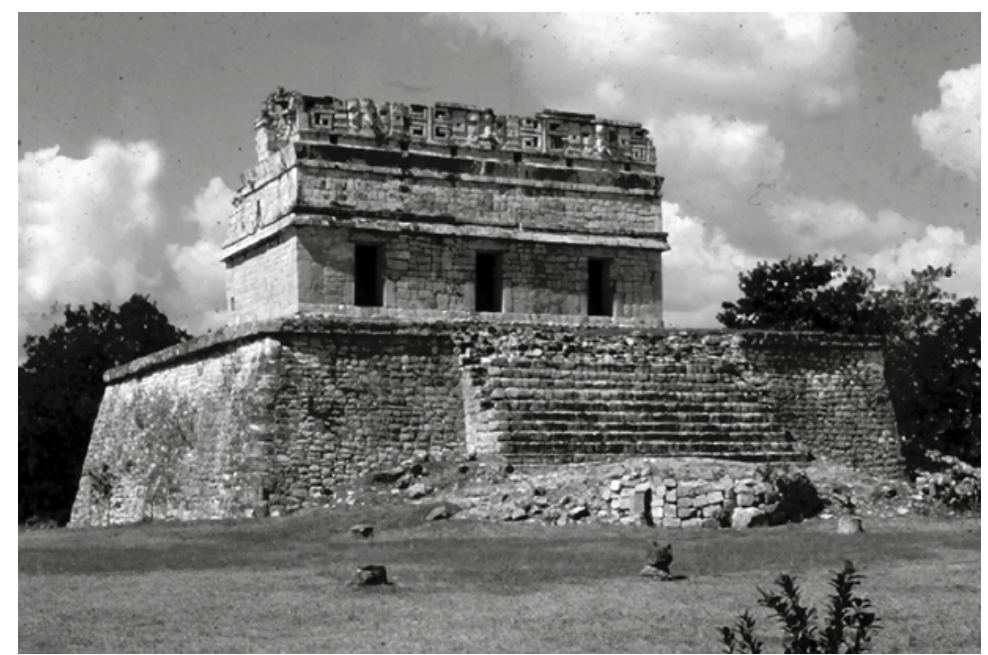

Figura 18. Chichén Itzá, La Casa Colorada (Fotografía de Antonio Benavides C.).

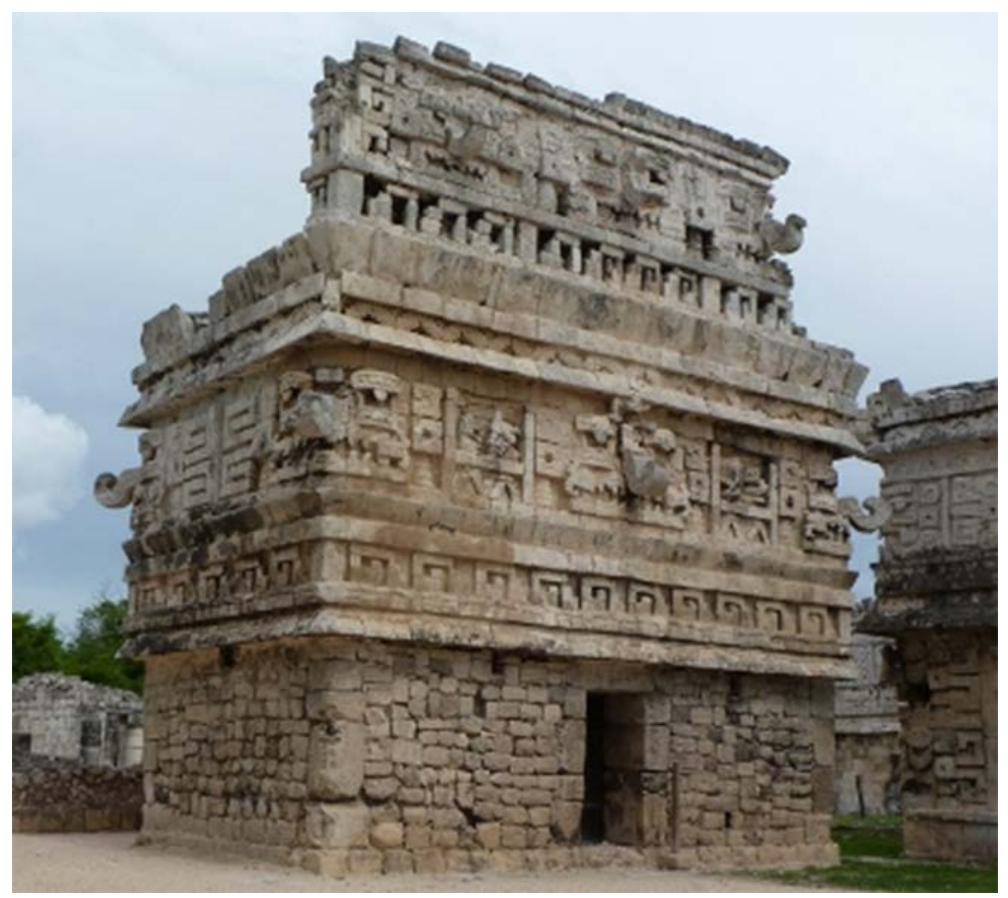

Figura 19. Chichén Itzá, La Iglesia (Fotografía de Antonio Benavides C.). 
Al finalizar el periodo Clásico la arquitectura monumental continuó edificándose en algunos asentamientos, pero desconocemos si se erigieron cresterías. Entre los pocos casos registrados se encuentran algunos edificios de Tulum, en cuyas azoteas se levantó una serie de lajas. El primer reporte de esas cresterías posclásicas se debe a Samuel K. Lothrop, quien estuvo allá en los años de 1920. En la Estructura 59, a poca distancia al norte del recinto amurallado, se registró un aposento de mampostería en cuyo techo se colocó un remate de poco menos de 2 metros de altura. Esa crestería mostraba nueve caladuras triangulares en un primer nivel y otras siete similares en el siguiente nivel. Los calados estaban soportados por muretes laterales (Lothrop, 1924: 118, fig. 112) (Figura 20).

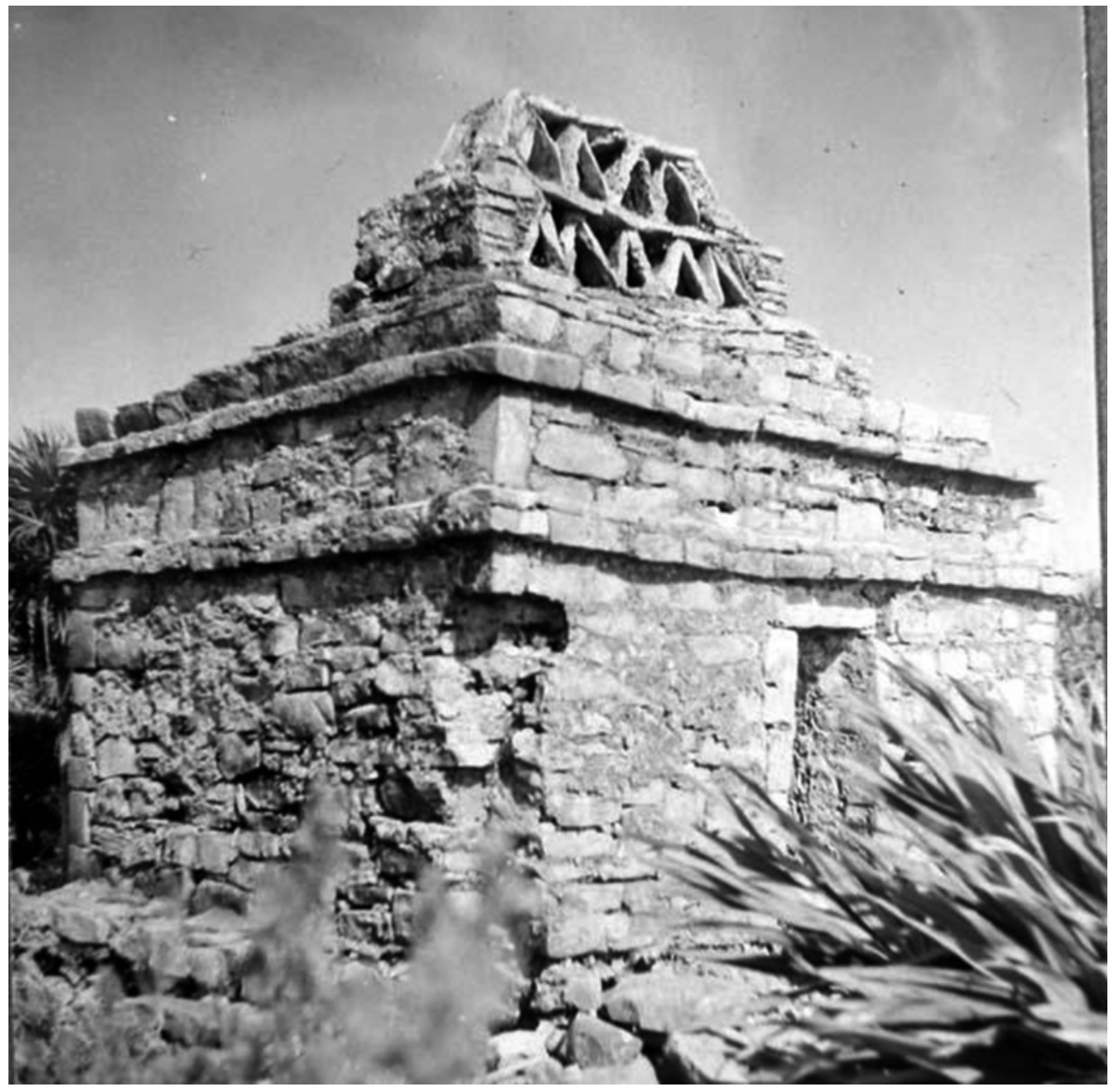

Figura 20. Estructura 59 de Tulum, según el registro de Lothrop (1924).

Poco más al norte, en Tancah, Lothrop (1924: 127) registró otra crestería pequeña pero vertical, y nuevamente al norte, en la Estructura I de Xelhá, reportó 
otro remate superior, ahora un murete calado, pero de forma triangular (Lothrop, 1924: 135, fig. 136) (Figura 21) que evoca aquellos remates del Palomar de Uxmal.

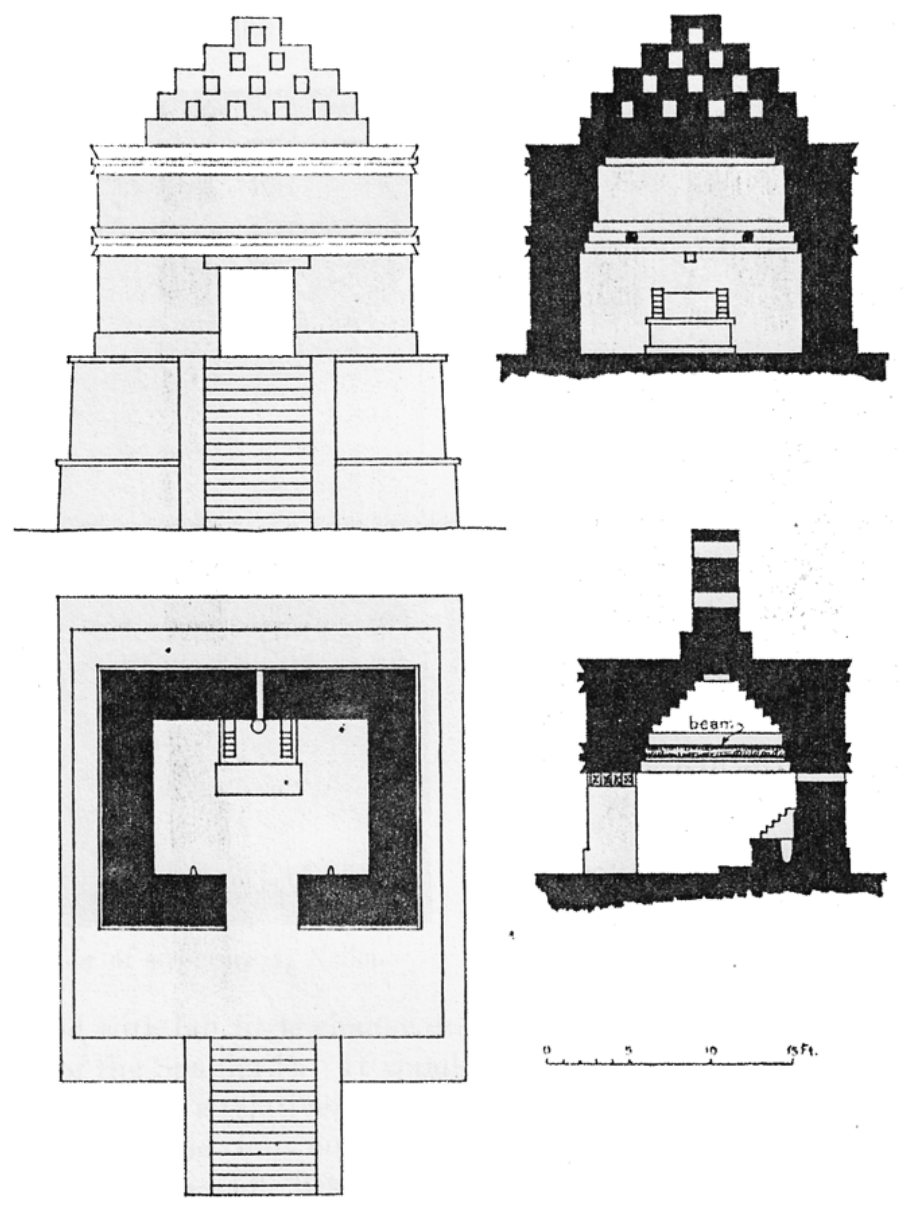

Figura 21. Registro de la Estructura 1 de Xelhá efectuado por Lothrop (1924).

\section{Algunas comparaciones}

La revisión de las cresterías mayas antes comentadas nos permitió efectuar un pequeño ejercicio en el que comparamos la superficie frontal expuesta. Sabemos que en varios casos los constructores aprovecharon ambos costados de la crestería para presentar imágenes diversas. No obstante, aquí sólo comparamos las partes delanteras de dichos remates (Cuadro 1). 


\begin{tabular}{|c|c|c|c|}
\hline Sitio & Largo y alto & $\mathrm{m}^{2}$ & Notas \\
\hline Chicanná, E. VI & $8.70 \times 3.30$ & 28.70 & Restaurada \\
\hline Chicanná, E. XX & $6.70 \times 1.50$ & 10.05 & Debió tener más altura \\
\hline Chichén Itzá, La Iglesia & $10 \times 3.10$ & 31 & Restaurada \\
\hline Chunyaxnic & $3.45 \times 2.20$ & 7.59 & Restaurada \\
\hline Cobá, E. IX & $16.50 \times 5$ & 82.50 & Restaurada \\
\hline Culucbalom, E. I & $12 \times 4.30$ & 51.60 & Quedan pocos vestigios \\
\hline Dzehkabtún & $14 \times 7$ & 98 & Restaurada \\
\hline Edzná & $11 \times 5.50$ & 60.50 & Restaurada e incompleta \\
\hline Hochob, E. II & $8.60 \times 3$ & 25.80 & Quedan pocos vestigios \\
\hline Kabah & $40 \times 4.50$ & 180 & Restaurada \\
\hline Kankí & $11.70 \times 3.70$ & 43.29 & Restaurada \\
\hline Kupaloma & $6.50 \times 3$ & 19.50 & Quedan pocos vestigios \\
\hline La Muralla & $17.60 \times 5$ & 88 & Quedan pocos vestigios \\
\hline Labná & $14.75 \times 4.05$ & 59 & Se conserva una tercera parte \\
\hline Mul Chic & $5.40 \times 2.80$ & 15.12 & Restaurada \\
\hline Okolhuitz & $6.25 \times 5$ & 31.25 & Se conservan dos terceras partes. \\
\hline Olvidado, 1 & $13 \times 2$ & 26 & Regularmente conservada \\
\hline Olvidado, 2 & $20 \times 3$ & 60 & Regularmente conservada \\
\hline Palenque, T. Cruz & $11 \times 5.50$ & 60.50 & Regularmente conservada \\
\hline Palenque, T. Sol & $8 \times 4$ & 32 & Restaurada \\
\hline Pared de los Reyes & $20.60 \times 2.98$ & 61.38 & Quedan pocos vestigios \\
\hline Río Bec B & $10.50 \times 3.70$ & 38.85 & Se conservan dos terceras partes. \\
\hline Sabacché & $8 \times 4$ & 32 & Quedan pocos vestigios \\
\hline Sacnicté & $7.30 \times 4$ & 29.20 & Quedan pocos vestigios \\
\hline Sayil & $12 \times 5$ & 60 & Regularmente conservada \\
\hline Tabasqueño & $6 \times 4$ & 24 & Se conserva muy poco \\
\hline Tikal, T. I & $10.50 \times 8.50$ & 89.25 & Restaurada \\
\hline Tikal, T. IV & $20 \times 12.86$ & 257.20 & Restaurada \\
\hline Tikal, T. V & $20 \times 12.50$ & 250 & Restaurada \\
\hline Tulum, E. 59 & $3.70 \times 1.80$ & 6.66 & Posclásico \\
\hline Uxmal, Palomar & $70 \times 7 \div 3$ & 163.33 & Se conserva buena parte \\
\hline Xelhá, E. I & $4 \times 2 \div 3$ & 2.66 & Posclásico \\
\hline Yaxchilán, E. 33 & $11.50 \times 3$ & 34.50 & Restaurada \\
\hline
\end{tabular}

Cuadro 1. Superficies de algunas cresterías mayas. 
Las superficies de mayor tamaño se encuentran en Tikal, siendo aquella del Templo IV la de mayores proporciones $\left(257 \mathrm{~m}^{2}\right)$. Le sigue la del Templo V $\left(250 \mathrm{~m}^{2}\right)$ $\mathrm{y}$, curiosamente, Uxmal, en el sector noroeste peninsular, se ubica en tercer lugar $\left(163 \mathrm{~m}^{2}\right)$. La siguiente superficie amplia en crestería se halla en Dzehkabtún $\left(98 \mathrm{~m}^{2}\right)$, en la región noreste de Campeche. En el extremo opuesto, las cresterías de menores dimensiones que se han registrado se encuentran en la costa oriental de Quintana Roo y son de tiempos posclásicos: Tancah, Tulum y Xelhá. Tales remates tuvieron calados geométricos y sólo cubrieron unos cuantos metros cuadrados.

También debemos comentar que seis de las cresterías registradas tuvieron un promedio de $60 \mathrm{~m}^{2}$, independientemente de si sus longitudes y alturas fueron distintas. Es el caso de dos inmuebles peteneros (Olvidado 2 y Pared de los Reyes), uno de la cuenca del Usumacinta (Palenque, Templo de la Cruz), así como de tres construcciones del norte peninsular: Edzná, Labná y Sayil. En estos cuatro últimos ejemplos las cresterías fueron erigidas sobre templos que coronan basamentos piramidales.

\section{Motivos y personajes}

Paul Gendrop (1984: 29) dejó en claro que el motivo central de las cresterías peteneras muestra a un personaje entronizado (como en Tikal y Yaxchilán) o bien a un personaje sentado (Palenque, Templo del Sol), así como mascarones de gran formato. Esta asociación entre seres humanos de elevada jerarquía y representaciones de seres fantásticos de grandes proporciones también es relativamente frecuente en otras imágenes oficiales monumentales, como las estelas. Gendrop (1984: 30) agrega que esta "exaltación de las familias en el poder" parece haber sido uno de los propósitos fundamentales de los gobernantes mayas no sólo en la región central sino también en las tierras bajas del norte. Así se explican "las grandes superficies planas de aquellas altas y a menudo muy anchas cresterías peninsulares".

Sin embargo, las distintas sociedades mayas generaron sus propios programas simbólico-ornamentales, como es el caso de aquellas representaciones en las que el amplio espacio de las cresterías permitió representar no sólo a un individuo sino a buen número de ellos. Tales son los casos de remates como los de Pared de los Reyes, La Muralla y Culucbalom, en el Petén compartido por Guatemala y Campeche (Ruppert y Denison, 1943), o bien de aquellos otros con muchos personajes de pie en los remates cimeros de los Edificios 2 y 5 de Hochob, ahora en la región de los Chenes.

Las escenas con jugadores de pelota parecen haber formado parte de los motivos importantes que se deseaba difundir visualmente. Eso parece indicar el caso de La Muralla antes citado y la crestería del basamento piramidal más elevado de Labná (Pollock, 1980: 34-37; Maler, 1997: 8). Esta última tuvo una superficie promedio de $59 \mathrm{~m}^{2}$ (14.75 $\mathrm{m}$ de largo por $4.05 \mathrm{~m}$ de alto). Otro posible ejemplo de personajes asociados a cresterías parece haber sido el de los nueve remates casi 
triangulares de la Casa de las Palomas de Uxmal. Aparentemente, cada triángulo calado enmarcaba a una figura antropomorfa.

Resumiendo, en la arquitectura maya parecen haber existido cuatro formatos principales a representar en las cresterías:

1. gobernante y ser fantástico (Tikal, Piedras Negras, Okolhuitz, Yaxchilán, Palenque);

2. grupos de funcionarios con o sin jugadores de pelota (La Muralla, Labná, Culucbalom, Hochob, Uxmal);

3. seres fantásticos (Tikal, Kankí, Xlabpak, Dzehkabtún, Uxmal, Chichén Itzá);

4. motivos geométricos y simbólicos (Mul Chic, Kupaloma, Kabah, Tulum).

Tras arduas jornadas para construir las pirámides y los edificios encima edificados, varios grupos de personas tuvieron, además, la tarea de trasladar hacia la cima más materiales y equipo para armar, conformar y decorar los imponentes remates arquitectónicos que hoy aún se conservan. Parafraseando a los antiguos romanos, es posible que algunos dinastas mayas tuvieran en mente aquella idea sintetizada por la frase aedifico ergo sum. Es interesante señalar que la construcción de esas pesadas estructuras, encima de masivas obras arquitectónicas, conllevó el esfuerzo y el ingenio de buen número de trabajadores. Finalmente, y quizá en aras de un mayor pragmatismo, llama la atención el cambio, a través del tiempo, de voluminosas cresterías por muros esbeltos y calados que incluso podían aprovecharse iconográficamente por ambos costados.

\section{Bibliografía}

Andrews, George F.

1986 Los estilos arquitectónicos del Puuc. Una nueva apreciación. México: Instituto Nacional de Antropología e Historia (Colección Científica).

1995 Pyramids and Palaces, Monsters and Masks. Vol. 1: Architecture of the Puuc Region. Lancaster: Labyrinthos.

1997 Pyramids and Palaces, Monsters and Masks. Vol. 2: Architecture of the Chenes Region. Lancaster: Labyrinthos.

Benavides C., Antonio

1981 Cobá. Una ciudad prehispánica de Quintana Roo: guía oficial. México: Instituto Nacional de Antropología e Historia, Centro Regional del Sureste.

1997 Edzná. Una ciudad prehispánica de Campeche. México: Instituto Nacional de Antropología e Historia, Universidad de Pittsburgh.

1998a “Xuelen's Buildings Have Been Restored”, Institute of Maya Studies Newsletter, 27 (5): 1-2.

1998b “Restauración arquitectónica de emergencia en Chelemí, Campeche”, La pintura mural prehispánica en México, 8-9: 31-34. México: Universidad Nacional Autónoma de México, Instituto de Investigaciones Estéticas. 
2004 "El asentamiento prehispánico de Okolhuitz, Campeche”, Homenaje a Jaime Litvak, pp. 317-330, Antonio Benavides, Linda Manzanilla y Lorena Mirambell (coords.). México: Instituto Nacional de Antropología e Historia, Universidad Nacional Autónoma de México, Instituto de Investigaciones Antropológicas (Colección Científica).

2012 "Intervención por los daños causados por la caída de un rayo sobre la crestería del Edificio de los Cinco Pisos de Edzná, Campeche”, Informe de Labores. Campeche: Centro InAH Campeche (Mecanuscrito inédito, 153 pp.).

2014 La arquitectura precolombina de Edzná, Campeche. Campeche: Gobierno Municipal 2012-2015.

2016 “Algunos ejemplos de almenas mayas", Arqueología, 51: 189-197.

Benavides C., Antonio y Sara Novelo O.

2007 "2006 Restoration Activities at Chunyaxnic, Campeche", Bulletin of the Institute of Maya Studies, 36 (7): 4-6.

Coe, William R.

1965 "Tikal. Ten Years of Study of a Maya Ruin in the Lowlands of Guatemala", Expedition, 8 (1): 5-56.

1967 Tikal. Guía de las antiguas ruinas mayas. Guatemala: Editorial Piedra Santa.

Fuente, Beatriz de la

1970 "La arquitectura de Tikal”, Anales del Instituto de Investigaciones Estéticas, 10 (39): 67-78. Dol: https://doi.org/10.22201/iie.18703062e.1970.39.909.

García Moll, Roberto

2003 La arquitectura de Yaxchilán. México: Plaza y Valdés, Instituto Nacional de Antropología e Historia.

Garza, Mercedes de la, Guillermo Bernal y Martha Cuevas

2012 Palenque-Lakamhá. Una presencia inmortal del pasado indígena. México: Fondo de Cultura Económica, El Colegio de México.

Gendrop, Paul

1975 "La evolución de la crestería en la arquitectura maya", Memorias de la XIII Mesa Redonda, I: 49-60. México: Sociedad Mexicana de Antropología.

1983 Los estilos Río Bec, Chenes y Puuc en la arquitectura maya. México: Universidad Nacional Autónoma de México.

1984 "La crestería maya y su posible simbolismo dinástico", Cuadernos de Arquitectura Mesoamericana, 1: 24-39. México: Universidad Nacional Autónoma de México.

1985 "Los remates o coronamientos de techo en la arquitectura mesoamericana", Cuadernos de Arquitectura Mesoamericana, 4: 47-50. México: Universidad Nacional Autónoma de México.

1997 Diccionario de arquitectura mesoamericana. México: Editorial Trillas.

Graham, Ian

1992 Corpus of Maya Hieroglyphic Inscriptions. Vol. 4, Part 2. Uxmal. Cambridge: Harvard University Press, Peabody Museum of Archaeology and Ethnology. 
Greene Robertson, Merle

1979 "A Sequence for Palenque Painting Techniques", Maya Archaeology and Ethnohistory, pp. 149-171, N. Hammond y G. Willey (eds.). Austin: University of Texas Press.

Harrison, Peter D.

1999 The Lords of Tikal: Rulers of an Ancient Maya City. Londres: Thames \& Hudson.

Lothrop, Samuel K.

1924 Tulum. An Archaeological Study of the East Coast of Yucatán. Washington: Carnegie Institution of Washington (Publication 335).

Maler, Teobert

1997 Peninsula Yucatán. Berlín: Bebruder Mann Verlag.

Marquina, Ignacio

1964 Arquitectura Prehispánica. México: Instituto Nacional de Antropología e Historia.

Michelet, Dominique, Nicolás Latsanopoulos y Julie Patrois

2004 "¿El ocaso de un estilo? Nota preliminar sobre la fachada norte del edificio con torres del Grupo A de Río Bec”, Journal de la Societé des Américanistes, 90 (1): 223-240.

Michelet, Dominique, Marie Charlotte Arnauld y Philippe Nondédéo

2007 "Río Bec, Campeche, al cabo de tres temporadas de investigaciones en el campo (2002-2004): datos preliminares”, El patrimonio arqueológico maya en Campeche: novedades, afectaciones y soluciones, pp. 131-158, Ernesto Vargas y Antonio Benavides (eds.). México: Universidad Nacional Autónoma de México, Instituto de Investigaciones Filológicas, Centro de Estudios Mayas (Cuadernos del Centro de Estudios Mayas, 35).

Paap, Iken y Antonio Benavides C.

2015 "Dzehkabtún, Campeche, y los resultados de las temporadas 2013/2014: mapeo, excavación y consolidación”, Encuentro Internacional Los Investigadores de la Cultura Maya, 23 (II): 101-122. Campeche: Universidad Autónoma de Campeche.

Piña Chán, Román

1964 "Algunas consideraciones sobre las pinturas de Mul Chic, Yucatán”, Estudios de Cultura Maya, 4: 63-78. DoI: http://dx.doi.org/10.19130/iifl.ecm.1964.4.231.

Pollock, Harry E. D.

1980 The Puuc. An Architectural Survey of the Hill Country of Yucatan and Northern Campeche, Mexico. Cambridge: Harvard University (Memoirs of the Peabody Museum of Archaeology \& Ethnology). 
Robina, Ricardo de

1956 "Estudio preliminar de las ruinas de Hochob, Municipio de Hopelchén, Campeche", tesis de licenciatura en Arquitectura. México: Universidad Nacional Autónoma de México, Facultad de Arquitectura.

Ruppert, Karl y John H. Denison

1943 Archaeological Reconnaissance in Campeche, Quintana Roo and Peten. Washington: Carnegie Institution of Washington (Publication 543).

Scherer, Andrew K.

2015 Mortuary Landscapes of the Classic Maya. Rituals of Body and Soul. Austin: University of Texas Press.

Sprajc, Iván (ed.)

2008 Reconocimiento arqueológico en el sureste del estado de Campeche, México: 19962005. Oxford: British Archaeological Reports Oxford Ltd (Paris Monographs in American Archaeology, 19. BAR International Series, 1742).

Stephens, John L.

1963 Incidents of Travel in Yucatan, 2 vols. Nueva York: Dover Publications Inc.

Stuart, David

2014 "The Reading of Two Dates from the Codz Pop at Kabah, Yucatan", Maya Decipherment. Ideas on Ancient Maya Writing and Iconography. Disponible en: $<$ mayadecipherment.com/?s= reading + of + two + dates $>$ [consultado el 7 de enero de 2019].

Thompson, Edward $\mathrm{H}$.

1889 "The Ruins of Labna". Manuscrito en el Museo Peabody. Cambridge: Harvard University.

Antonio Benavides Castillo. Mexicano. Arqueólogo por la Escuela Nacional de Antropología e Historia; maestro en Antropología por la Universidad Nacional Autónoma de México y doctor en Estudios Mesoamericanos por la misma. Es investigador del Centro Campeche, del Instituto Nacional de Antropología e Historia, y sus principales líneas de investigación se han centrado en el estudio de la arquitectura, el patrón de asentamiento y la iconografía maya de la época prehispánica. Actualmente desarrolla el proyecto "Arqueología de Santa Rosa Xtampak". Entre sus publicaciones más recientes se encuentran: "La Tapa de bóveda 23 de Santa Rosa Xtampak" (en coautoría), "Elementos prehispánicos del municipio de Champotón" y "Apuntes sobre el comercio maya precolombino en la península de Yucatán”.

abc999@prodigy.net.mx 